https://helda.helsinki.fi

\title{
Vitamins and minerals
}

\section{Hemilä, Harri}

Birkhäuser

2009

Hemilä , H 2009 , Vitamins and minerals . in R Eccles \& O Weber (eds), Common cold .

Birkhauser advances in infectious diseases , Birkhäuser, Basel , pp. 275-307 . https://doi.org/10.1007/978-3-7643-9

http://hdl.handle.net/10138/228060

https://doi.org/10.1007/978-3-7643-9912-2_13

acceptedVersion

Downloaded from Helda, University of Helsinki institutional repository.

This is an electronic reprint of the original article.

This reprint may differ from the original in pagination and typographic detail.

Please cite the original version. 


\title{
Eccles /Birkhauser / Treatment and Prevention Options:
}

\section{Vitamins and Minerals}

\author{
Harri Hemilä version 11 May 2009 \\ Harri Hemilä \\ Department of Public Health \\ University of Helsinki, \\ Helsinki, \\ FIN-00014 Finland \\ harri.hemila@helsinki.fi
}

\begin{abstract}
Taking vitamins and minerals to fight against the the common cold is popular in the western countries and thus it is important to find out whether they are effective or not. A large number of trials have found that regular vitamin $\mathrm{C}$ supplementation shortens the duration of colds and probably it is beneficial when administered therapeutically, starting soon after the onset of the symptoms. Zinc lozenges have reduced the duration of common cold symptoms when the total daily zinc doses were over $70 \mathrm{mg}$. Consequently, both vitamin $\mathrm{C}$ and zinc have a potential for becoming options for treating the common cold, but more research is needed to find out optimal doses and treatment strategies. The prophylactic effect of vitamins and minerals has also been examined in several trials. Vitamin $\mathrm{C}$ has no preventive effect in the general community, but it may reduce the incidence of respiratory symptoms in restricted population groups such as people under heavy acute physical stress and people who have particularly low dietary intake of vitamin C. There is no evidence that vitamin E supplementation prevents colds in middle-aged people. Nevertheless, the effect of vitamin $\mathrm{E}$ in elderly males is heterogeneous and further studies are warranted in elderly people. $\beta$-Carotene has been promoted for improving the immune system, but there is no evidence that it has effects against colds. The effects of multivitamin and multimineral combinations against the respiratory tract infections of elderly people have been studied in several trials, but there has been a nearly uniform lack of effect. Vitamin D and folic acid have been constituents of the multivitamin supplements, and the lack of benefit of the supplements implies that increasing the intake of vitamin D or folic acid in elderly people would not have substantial preventive effects against respiratory infections.
\end{abstract}




\section{Introduction}

The term 'the common cold' does not denote any precisely defined disease, yet the symptoms of this illness are personally familiar to practically everybody. Although the great majority of common cold episodes are caused by the group of respiratory viruses, the symptom-based definition of the 'common cold' also covers some diseases caused by non-respiratory viruses and even some bacterial infections and allergies. The large number of etiological agents, the benign character of the disease, and the high cost of the virologic tests (e.g., \$ 700 per patient in one study [1]) mean that a functional everyday definition of the 'common cold' cannot be based on laboratory tests, but must be based on symptoms. Furthermore, a chest x-ray has no relevance in excluding pneumonia when the patient is not seriously ill.

The liberal definition of 'the common cold' has implications for research in the general community. First, it is much cheaper to count the number of respiratory-symptom episodes and the days of illness compared with searching for the etiologic agent. Second, the general community does not have access to rapid tests that reveal the cause of the disease. Therefore a treatment that is focused on a specific agent cannot be efficiently used in the community anyway. Third, the rationale for vitamin and mineral supplementation is based on the assumption of non-specific effects on the immune system and against diverse infections. Thus, the symptom based definition is particularly appropriate when examining whether vitamins or minerals have non-specific effects relevant at the public health level.

The primary focus of this chapter is on the common cold type of symptoms; however, the border between upper respiratory infections (URI) and lower respiratory infections (LRI) is ambiguous. For example, computer tomography identifies many more cases of pneumonia compared with a chest X-ray [2], and thus a patient may have an URI simply because he or she has not been studied with sophisticated methods. In some trials all respiratory infections or all infections were combined. Those trials are not excluded from this chapter, because the great majority of infections in the general community are URI so that the wide definitions primarily measure the URI and the common cold.

Taking vitamins to improve health and the immune system is popular in the western countries. About half of the elderly in the USA take some vitamin or mineral supplements [3]. Therefore it is important to find out whether they have effects on respiratory infections. If vitamins or minerals are shown to be effective, their use may be encouraged. If they are ineffective, their use should be discouraged. I focus on the findings of controlled trials and describe the biological rationales only to a minor extent. The P-values presented are consistently two-tailed. 


\section{Vitamin C}

In the early 1970s, Linus Pauling published a meta-analysis of four placebo-controlled trials on vitamin $\mathrm{C}$ and the common cold and concluded that there was strong evidence that vitamin $\mathrm{C}$ reduced 'integrated morbidity' caused by colds, meaning the combination of incidence and severity [4]. In a second meta-analysis Pauling restricted to the two methodologically best trials, and calculated a combined $\mathrm{P}=0.001$ to reject the hypothesis that vitamin $\mathrm{C}$ equals placebo [5-7].

Pauling's proposal that vitamin $\mathrm{C}$ might affect infections was not novel. Vitamin $\mathrm{C}$ deficiency, scurvy, is associated with a high risk of pneumonia [8,9], and after vitamin $\mathrm{C}$ was identified in the 1930s, there was much interest in its effects on infections [9-11]. In 1942, two trials with schoolchildren found that vitamin $C$ reduced the incidence of colds and pneumonia [6,12-14]. After the World War, the Sheffield trial examined the effects of vitamin $\mathrm{C}$ deprivation and found that the mean duration of colds was 6.4 days in vitamin C-deprived subjects and 3.3 days in non-deprived subjects [15]. Nevertheless, these early studies did not affect the main-stream medicine which considered that vitamin $\mathrm{C}$ was effective only against scurvy.

Methodologically, Pauling's work was novel as his meta-analyses were among the very first in medicine. Furthermore, he was a public figure because of his Nobel prizes in Chemistry (1954) and in Peace (1963) [14,16] and therefore his message, spread also in popular books $[17,18]$, received wide audiences. Although Pauling was unable to convince the medical community of the benefits of vitamin $\mathrm{C}$, his activity led to a series of new trials.

Before Pauling's first book was published [17], only one trial had examined the effects of regular high-dose vitamin $\mathrm{C}, \geq 1 \mathrm{~g} /$ day, on the common cold [7], whereas a dozen new trials were carried out within a few years after Pauling made the issue popular (Fig. 1). In the mid-1970s, the interest in this issue evaporated, not because of consistently negative results, but for reasons described at the end of this section.

In his analyses, Pauling used 'integrated morbidity' - the combination of incidence and severity. However, the effects of vitamin $\mathrm{C}$ on the incidence and severity of colds are different and it is more useful to analyze them separately.

\section{Incidence of the common cold}

In our Cochrane review on vitamin $\mathrm{C}$ and the common cold, we restricted to placebo-controlled trials which used $\geq 0.2 \mathrm{~g} /$ day of vitamin $\mathrm{C}$ [24]. We used the number of participants catching a cold as the incidence outcome, and analyzed separately trials in the general community and trials with 
participants under heavy acute physical stress. In 24 general community trials with 10,708 participants, vitamin $\mathrm{C}$ had no effect on common cold incidence: $\mathrm{RR}=0.98$ (95\% CI: 0.95-1.00). In another meta-analysis restricting to the six largest trials which had used $\geq 1 \mathrm{~g} /$ day of vitamin $\mathrm{C}$, the 5480 common cold episodes were divided equally between the vitamin $\mathrm{C}$ and placebo groups: $\mathrm{RR}=0.99(0.93-1.04)[22]$.

Thus, there is strong evidence that vitamin $\mathrm{C}$ does not reduce the average incidence of colds in the general western populations. However, the picture is more complex than indicated by the narrow confidence intervals of the above meta-analyses. It is possible that vitamin $\mathrm{C}$ affects susceptibility to the common cold under special conditions or in specific subpopulations.

In 1996 I pooled the results of three trials with participants under heavy acute physical stress and found that vitamin $\mathrm{C}$ halved the incidence of colds: $\mathrm{RR}=0.50$ (95\% CI: 0.35-0.69)[25]. Thereafter three new trials with similar participants reported consistent results $[14,24,26]$. Four of the six trials were with marathon runners [20,27-29], one with Canadian troops in a short winter exercise [30], and one with Swiss schoolchildren in a skiing camp in the Swiss Alps [7]. Thus, the conditions were extraordinary. Furthermore, even though the authors of the six papers thought that they were measuring the common cold, the etiology of the recorded respiratory symptoms is not evident. Running for hours causes severe physical stress to the airways and can cause exerciseinduced bronchoconstriction (EIB) [31]. Thus, cough and sore throat after a marathon run does not necessarily imply a viral cause. Possibly the respiratory symptoms in the six trials were caused by the combination of viral infections and EIB. In three laboratory studies vitamin C prevented EIB [3234]. Thus, the benefit of vitamin $\mathrm{C}$ in the six trials with physically stressed participants may be caused by effects against both viral infections and EIB.

A further subpopulation in which vitamin $\mathrm{C}$ supplementation may affect common cold incidence is people who have low dietary vitamin C intake, 'marginal deficiency.' Among the western countries, dietary vitamin $\mathrm{C}$ intake has been particularly low in the UK [22]. In four trials with British males, vitamin $\mathrm{C}$ supplementation reduced common cold incidence: $\mathrm{RR}=0.70$ (95\% CI: 0.60$0.81)$ whereas in four trials with females it had no effect: $R R=0.95(0.86-1.04)[12,22,35-38]$. Substantial divergence between sexes was also seen in two trials that reported results separately for both sexes [38-40]. The most direct evidence supporting the 'treatment of marginal deficiency' explanation is the trial by Baird et al. as they administered only $0.08 \mathrm{~g} /$ day of vitamin $\mathrm{C}$, yet vitamin C had significant effect $[22,38]$. Modification of vitamin C supplementation effect by dietary vitamin C was also suggested by the Anderson et al. trial in Canada [41], as they found greater benefit of vitamin $\mathrm{C}$ for those who had low intake of juices (Table 1); however, their subgroup analysis was not focused on incidence but on the total number of sickness days during the trial. Anderson also found 
other differences between subgroups so that regular vitamin $\mathrm{C}$ supplementation appeared more beneficial for people who had contact with children, were often in crowds, or had often colds (Table $1)$.

\section{Duration and severity of the common cold}

Regular vitamin $\mathrm{C}$ administration reduces the duration of colds that occur during the supplementation period. In 18 trials with 7242 adults, $\geq 0.2 \mathrm{~g} /$ day of vitamin $\mathrm{C}$ reduced the duration of colds on average by $8 \%(\mathrm{P}=0.002)$ and in 12 trials with 2434 children by $13 \%(\mathrm{P}=0.0008)$ [24]. However, these P-values underestimate the differences between the study groups, because the calculations are based on the duration of symptoms. For the patient and the society, the days off work or school, or the subjective severity may be much more relevant outcomes than the period the nose is running, and vitamin $\mathrm{C}$ might have a different effect on different outcomes.

With 615 Swedish schoolchildren, Ludvigsson et al. [43] found that $1 \mathrm{~g} /$ day vitamin C shortened the symptoms of URI by just $6 \%(\mathrm{P}=0.6)$, but the 'absence from school' because of URI by $14 \%(\mathrm{P}=0.016)$. With 818 Canadian adults, Anderson et al. [41] found that common cold symptoms were shortened by $5 \%(\mathrm{P}=0.3)$, but days 'confined to house' because of colds were shortened by $21 \%(\mathrm{P}=0.015)$.

There is evidence suggesting dose-dependency in the vitamin C effect [44]. In five trials with adults administered $1 \mathrm{~g}$ /day of vitamin $\mathrm{C}$, the mean decrease in cold duration was only $7 \%$, whereas in two trials with children administered $2 \mathrm{~g}$ /day the mean decrease was four times higher, $26 \%$ [14,44-46]. Children administered $1 \mathrm{~g} /$ day and adults administered $\geq 2 \mathrm{~g} /$ day were in the middle [44]. This pattern of results supports dose dependency, given also the lower average weight of children. Nevertheless, the outcomes and study conditions vary between trials hampering the comparison of different trials. The most direct evidence indicating dose-dependency was seen in the Karlowski trial with adults in which $6 \mathrm{~g} /$ day caused twice the decrease in common cold duration compared with the dose of 3 g/day $[44,47,48]$. Thus, it seems possible that trials with low doses give an underestimate of the potential benefit of vitamin $\mathrm{C}$.

\section{Therapeutic effect of vitamin $C$}

The great majority of vitamin $\mathrm{C}$ trials examined the effect of regular supplementation, meaning that the vitamin was administered each day over the trial. However, if the purpose is to alleviate common cold symptoms, it is much more reasonable to administer vitamin $\mathrm{C}$ therapeutically, starting 
immediately after the first symptoms. Unfortunately, few therapeutic trials have been carried out and their results are heterogeneous. Some of the negative findings may be explained by a low dose or a short treatment of 3 days or less $[14,19,44,49]$.

In a 5-day therapeutic trial, Anderson et al. administered $1.5 \mathrm{~g}$ of vitamin $\mathrm{C}$ on the first day and $1 \mathrm{~g} /$ day on the following days [42]. They found a $25 \%$ reduction in 'days confined indoors' and a $29 \%$ reduction in 'days felt feverish' ( $\mathrm{P}<0.05$ for both). Anderson also found variation between subgroups so that therapeutic vitamin $\mathrm{C}$ seemed more beneficial for people who had contact with children or low intake of juices (Table 1). Karlowski tested 5-day therapeutic supplementation of 3 $\mathrm{g} /$ day of vitamin $\mathrm{C}$ and found that the duration of colds was decreased by $10 \%(\mathrm{P}=0.10)[47,48]$.

In their 1974 trial, Anderson et al. compared 4 grams and 8 grams when administered only on the first day of the common cold [50]. In the 8-gram group, $46 \%$ of colds lasted for just one day, whereas in the 4-gram group, $39 \%$ of colds lasted for one day only. Thus, about $6 \%$ of participants found benefit from the 8 grams on the first day of the cold in the form of cold lasting just one day instead of longer ( $\mathrm{P}=0.046,[14$ p. 42]). Thus, this comparison indicates dose dependency in a therapeutic setting.

In the regular supplementation trials, the effect of vitamin $C$ has been greater on children than on adults, but no therapeutic trials with children have been carried out.

Vitamin $\mathrm{C}$ is safe in high doses. For example, in a pharmacokinetic study, $100 \mathrm{~g}$ of vitamin $\mathrm{C}$ was administered intravenously over a few hours without reported adverse effects, and this led to plasma concentrations that were 100 times the level reached by oral administration of high doses [51]. High intravenous vitamin $\mathrm{C}$ doses, up to $65 \mathrm{~g}$ twice per week, have been administered for cancer patients for 10 months [52] also indicating the safety of vitamin C. Several reviewers have concluded that vitamin $\mathrm{C}$ is safe in long term use in doses ranging to several grams per day $[53,54]$. Thus, there is no justification to assume that therapeutic high dose administration of vitamin $\mathrm{C}$ for colds for the duration of a week would cause harmful effects.

Finally, although a tablet is practical and the most common form of administering vitamin $\mathrm{C}$, it is worth noting that administering vitamin $\mathrm{C}$ powder directly into the nose has also been suggested for treating the common cold [55].

\section{Mechanism of the effect by vitamin $C$}

Proponents of evidence-based medicine emphasize that the evaluation of interventions should be based on controlled trials and not on the biological plausibility. Therefore this chapter is focused on trials. Nevertheless, dozens of studies have found that vitamin $\mathrm{C}$ may affect, for example, 
phagocytosis and chemotaxis of leucocytes, replication of viruses, and production of interferon [11,56-60]. Vitamin $\mathrm{C}$ is an efficient antioxidant and the effects on the immune system can be explained by the protection against oxidative stress generated during infections [19,61-65]. Dozens of animal studies found that vitamin $\mathrm{C}$ reduces the incidence and severity of bacterial and viral infections indicating that the vitamin has physiological effects on infections, and not just on laboratory measures of the immune system [66]. Furthermore, heavy physical stress generates oxidative stress $[67,68]$ and the antioxidant role of vitamin $C$ can thus explain also its effects on respiratory symptoms in physically stressed people.

\section{Problems in influential papers on vitamin $C$ and the common cold}

Given the evidence by 1975 indicating that regular $\geq 2 \mathrm{~g} /$ day vitamin $\mathrm{C}$ reduces the duration and severity of colds, at the level of $\mathrm{P}=0.000002$ [69], it is puzzling that major textbooks have rejected the possibility that vitamin $\mathrm{C}$ might be beneficial against colds [14]. The interest in vitamin $\mathrm{C}$ and colds disappeared in the middle of the 1970s (Fig. 1). This waning interest was caused by the publication of two negative reviews in wide-circulation journals [70,71] and a particularly influential trial, carried out at the National Institutes of Health and published in JAMA, which concluded that the apparent benefit of vitamin C was explained by the placebo effect [47]. Furthermore, the Karlowski trial [47] and the Dykes and Meier review [71] were published in the same issue of JAMA, and Thomas Chalmers, a pioneer of controlled trials, was both the principal investigator of the Karlowski trial [47] and the author of the other review [70]. For such reasons this package of three papers from 1975 still has great impact on discussions on vitamin $\mathrm{C}$ and the common cold.

Chalmers' 1975 review [70] contains a large number of serious errors, such as the data was inconsistent with the original published data, there were errors in calculation, the selection of trials was inconsistent, and in some trials a clinically less meaningful outcome was selected [72,73]. Dykes and Meier's 1975 review was also biased [69,74] and Pauling wrote a commentary on their review and submitted his manuscript to JAMA. However, Pauling's manuscript was rejected even after he twice made revisions to meet the suggestions of the referees and the manuscript was finally published in a minor journal $[75,76]$. The rejection of Pauling's commentary was quite a strange policy by $J A M A$, since the readers were thereby prevented from seeing the other side of an important scientific controversy.

In their 1975 trial, Karlowski et al. carried out a subgroup analysis by the guessing of treatment by the participants and concluded that: "The effects demonstrated might be explained equally well by a break in the double blind" [47]. However, they excluded $42 \%$ of recorded common 
cold episodes from their subgroup analysis without any explanations and their 'placebo effect' explanation is not even consistent with the data they reported [48,77-79].

Some other reviews on vitamin $\mathrm{C}$ and the common cold $[80,81]$ are also biased $[69,82,83]$. However, their impact in the medical literature is far lower than that of the three papers from 1975 described above. Nevertheless, the problems in these other reviews also show that there is wide spread bias against the potential benefits of vitamin $\mathrm{C}$ against the common cold.

On his part, Pauling was too optimistic of the potential benefits of vitamin C $[44,49,84]$. The benefit in the two methodologically best trials analyzed by him [5] can be explained by the low dietary vitamin C intake during the war years in the USA [6] and heavy acute physical stress [7], and, while those findings probably reflect real biological effects, they cannot be extrapolated to the general western communities. Nevertheless, Pauling was correct in his conclusion that the effects of vitamin $\mathrm{C}$ are not limited to preventing scurvy. 


\section{Vitamin E}

Vitamin E has diverse effects on the immune system, which have been assumed to be beneficial $[60,85,86]$. However, in two studies vitamin E supplementation reduced the bactericidal activity of leukocytes indicating that it can also cause harms on the immune system $[87,88]$. In dozens of animal studies vitamin E protected against viral and bacterial infections [66]; but increased the severity of infections in a few [89-91].

Two trials examined the effect of $200 \mathrm{mg} /$ day vitamin $\mathrm{E}$ on acute respiratory infections in people older than 60 years [92,93]. Graat et al. carried out a 15-month trial with 652 noninstitutionalized Dutch people [92]. Vitamin E had no effect on the number of respiratory infections, but, paradoxically, it made the episodes more severe. In the vitamin E group, there were more participants with fever $(\mathrm{P}=0.009)$ and restriction of activity $(\mathrm{P}=0.02)$, and the median number of symptoms was higher $(\mathrm{P}=0.03)$ and the total duration of illness was longer $(\mathrm{P}=0.02)$. Thus, vitamin $\mathrm{E}$ was harmful for this population and the trial should not be dismissed when considering the potential harms of vitamin E supplementation [94].

Meydani et al. carried out a one-year trial with 617 nursing home residents in the USA [93]. They reported the intention-to-treat results, favoured by biostatisticians, in table 3 calculating 13 separate comparisons between the vitamin E and placebo groups. Thus, the table is an example of the multiple comparisons problem. If we calculate 20 statistical tests, when no real difference exists, random variation generates on average one false positive finding, $\mathrm{P}<0.05$. The 13 calculations found only one significant difference and very marginally so: $\mathrm{P}=0.048$ [93]. Therefore the variations in their table 3 are explained by chance, yet the authors made an unjustified extrapolation that vitamin $\mathrm{E}$ supplementation would lead to "more than 5 million fewer elderly nursing home residents contracting upper respiratory infections in a year" in the USA [95].

The large scale ATBC Study with 29,133 Finnish male smokers examined the effects of 6year vitamin E supplementation [96]. Vitamin E, $50 \mathrm{mg} /$ day, had no overall effect on common cold incidence: $\mathrm{RR}=0.99$ [97]. However, there was heterogeneity so that age and smoking modified the effect of vitamin $\mathrm{E}$ (Fig. 2, Table 2). In the young and less smoking males vitamin $\mathrm{E}$ increased the incidence of colds. In the old males, the effect diverged so that vitamin E increased the incidence of colds in heavy smokers but reduced it in those who smoked less. Smoking also modified the effect of vitamin $\mathrm{E}$ on pneumonia risk, reducing the risk in those who were least exposed to smoking [99].

Heavy exercise causes oxidative stress and, as an antioxidant, vitamin E might protect against it $[67,68]$. In the ATBC Study, vitamin E had no effect on the incidence of colds in those who exercised at their leisure time [100] but halved the incidence of pneumonia [101]. 
Thus, in the ATBC Study vitamin E supplementation increased, decreased or had no effect on the incidence of the common cold, depending on age and the level of smoking. The numerical estimates of Table 2 are less essential than the evidence of heterogeneity. When the effect of vitamin E depends on the characteristics of people, the estimates of intervention effect obtained in a trial or a subgroup cannot be confidently generalized to other population groups.

The firm evidence of heterogeneity in the effect of vitamin $\mathrm{E}$ on respiratory infections refutes the notion that it is noneffective for all people. Nevertheless, the effect of vitamin $E$ on the common cold is modest even in the old and less smoking males (Table 2). Considering the cost of taking supplements over a year, and the mild character of the disease occurring less frequently than once per year, it does not seem justified to propose any people to take vitamin E to prevent respiratory infections. Furthermore, vitamin E has increased the incidence and severity of respiratory infections in some population groups (Table 2 and [92]). Nevertheless, further studies with old people are warranted. 


\section{$\beta$-Carotene}

The carotenoids is a group of hundreds of pigments that are widespread in plants, of which only about a dozen occur in human food. $\beta$-Carotene is important as a precursor of vitamin $A$, but there is also interest in the effect of $\beta$-carotene per se on health. $\beta$-Carotene has effects on the immune system and it has been considered potentially beneficial for improving the immune system in aged people $[60,85,102,103]$. However, few controlled trials have examined the effect of $\beta$-carotene on infections.

In the ATBC Study, $20 \mathrm{mg} / \mathrm{day} \beta$-carotene had no overall effect on the incidence of the common cold: $\mathrm{RR}=1.00$ [97]. Nevertheless, there was significant age- and smoking-dependent variation in the $\beta$-carotene effect. In the young and less smoking participants and in the old heavily smoking participants, $\beta$-carotene increased the incidence of colds, but had no effect in other subgroups (Fig. 3, Table 3). Smoking also modified the effect of $\beta$-carotene on pneumonia risk [99].

In several multivitamin-multimineral trials with old people, $\beta$-carotene was one constituent of the supplements in the range of 1.2 to $6 \mathrm{mg} /$ day (next section). These trials did not find benefit of supplementation, which refutes the notion that increasing $\beta$-carotene intake might effectively reduce respiratory infections in old people.

$\beta$-Carotene is an antioxidant and potential benefits might be emphasized in physically stressed people. In the ATBC Study, $\beta$-carotene increased the incidence of colds in males who exercised heavily at leisure: $\mathrm{RR}=1.25$ (95\% CI: 1.09-1.44) [100]. In physically active ATBC Study participants, $\beta$-carotene nonsignificantly increased pneumonia risk [101].

Two large trials found that $\beta$-carotene supplementation increased mortality of people who had been smoking cigarettes or exposed to asbestos $[96,104]$. Given the harmful effects of $\beta$ carotene, as seen by the increase in respiratory infections and mortality, self-supplementation should be discouraged. There should be firm justification for further trials exposing people to it. 


\section{Multivitamin and multimineral supplements}

If a multivitamin-multimineral supplement has no effect on infections, it seems justified to argue that there is a lack of effect by each constituent of the supplement. Another way to interpret a negative finding is to assume that some constituent is beneficial, whereas some other constituent(s) annuls that benefit, but such reasoning requires explicit supportive evidence. In contrast, if a multivitaminmultimineral group does differ from the placebo group, we cannot draw specific conclusions because the effect can be caused by any single substance or the combination of several of them together. In this respect the implications are quite different when the result of a multivitamin and multimineral trial is positive or negative.

The multivitamin-multimineral trials have examined old people with the rationale that nutritional supplements, and antioxidants in particular, might prevent the decline in immune functions of the aged [85]. The frequently cited multivitamin-multimineral trial by Chandra [105] is excluded because a later paper based on the same data was shown to be fabricated and severe suspicions of the original 1992 paper were also expressed [106-108].

The definition of infection outcome has been variable in the trials of Table 4. Whereas Liu et al. separated URI and LRI [114], the majority of the trials combined all respiratory infections or all infections together. However, the majority of infections in the general community consists of URI, and therefore the group of all infections largely reflects the incidence of the URI.

There is a nearly uniform lack of benefit from multivitamin and multimineral supplementation against respiratory infections (Table 4). Girodon et al. found reduction in infections by the combination of zinc and selenium [110]. However, no effect of zinc and selenium was found in the larger trial by the same authors [111], or in trials which included zinc or/and selenium in their supplements [92,109,113,114].

Another positive result was by Barringer et al. with type 2 diabetics [112]. The effect of vitamin E was divergent between participants who had diabetes and those who did not have (Table 4). Still, the results are odd. Among the non-supplemented participants, infections were more common in the diabetic participants: $92 \%$ (25/27), compared with the non-diabetics: $60 \%$ (24/40), which is reasonable because susceptibility to infections is higher in diabetics. However, the incidence of infections was substantially lower in supplemented diabetics: 17\% (4/24), than in supplemented non-diabetics: 59\% (23/39). This is illogical because it means that supplementation would make diabetics more resistant to infections than non-diabetics. Thus, Barringer's findings with the small number of diabetics $(n=51)$ should be considered as a justification for further trials but not for supplementing diabetics with vitamins. 
Excluding the two positive findings leaves no evidence that multivitamins and multiminerals would influence the risk of respiratory infections in old people (Table 4). Furthermore, following the argument of the first paragraph of this section, these trials also indicate that none of the following substances has a substantial effect on respiratory infections in the old people: vitamin D, folic acid, vitamin A, thiamin, riboflavin, niacin, pyridoxine, panthotenic acid, cyanocobalamin, iodide, iron, calcium, magnesium, manganese and copper, because they were included in the supplement of four or more of the trials in Table 4.

The findings of the trials in Table 4 indicate that there is so far no justification to supplement old people with vitamins for the purpose of reducing respiratory infections. Nevertheless, the heterogeneity seen in the ATBC Study complicates this question (Figs 2 and 3). Vitamin E and $\beta$ carotene had no effect in participants who were somewhat over 60 years, whereas both substances had significant effects on those who were over 70 (Tables 2 and 3). The multivitamin-multimineral trials of Table 4 are small, with a maximum of 1809 infection episodes recorded in Avenell's trial [113]. In contrast, Fig. 2 is based on 55,770 common cold episodes providing statistical power to carry out subgroup analyses of age-dependency. Thus, there is justification to study the effects of vitamin $\mathrm{E}$ in old people, even though the multivitamin supplements containing vitamin $\mathrm{E}$ did not find any benefit for old people (Table 4). 


\section{Zinc}

Zinc deficiency affects the immune system and increases the risk of infections. In developing countries zinc supplementation has reduced the risk of childhood pneumonia [115-117] and in Turkey zinc reduced the risk of the common cold in children $[118,119]$. Although these studies indicate that the level of zinc intake has clinically important effects on the immune system, the findings cannot be extrapolated to developed countries. For example, multivitamin-mineral supplements containing 10-22 mg/day zinc had no effect on the incidence of respiratory infections in old people (Table 4).

In developed countries the interest in zinc for treating the common cold is primarily based on the rationalization that zinc lozenges may cause local effects in the oral cavity. The research on zinc lozenges for treating the common cold started from a serendipitous observation that colds of a young child with leukemia disappeared when she started to dissolve therapeutic zinc tablets in her mouth instead of swallowing them [120].

Zinc has various effects on the immune system [121], inhibits the replication of rhinovirus and respiratory syncytial virus [122-124], and enhances the effect of interferon [125]. Non-immune mechanisms have also been proposed to explain the effect of zinc lozenges on the common cold $[126,127]$. For the interpretation of the controlled trials with zinc lozenges, the most essential hypothesis is that the level of free zinc ions is a crucial determinant of efficacy [128-133].

\section{Effect of zinc lozenges on the duration of common cold symptoms}

Table 5 lists the placebo-controlled trials in which the effect of zinc lozenges on natural common cold infections was studied. The trials are ordered by the calculated total daily dose of zinc from the lozenges. The reporting of outcomes is somewhat variable, but most trials reported the average duration of colds. The table shows that a large proportion of the variation in the results can be explained by the zinc dosage. None of the five trials that used less than $70 \mathrm{mg} / \mathrm{day}$ of zinc found effect, whereas seven of the eight trials that used over $70 \mathrm{mg} /$ day of zinc found significant benefit of the lozenges. Evidently, the $70 \mathrm{mg} /$ day should not be considered as a biological limit, instead it is a pragmatic limit for analyzing the trials by zinc dosage.

In Table 5 the dose-response relation is examined using the total zinc dose as the explanatory variable. However, this is a simplification because several of the lozenges contained substances which bind zinc ions, such as citrate, reducing the free zinc ion levels. This argumentation has been elaborated in detail by several authors [128-133] and the arguments are not repeated here. Martin 
assumed that chewing a zinc-citric acid lozenge would decrease the $\mathrm{pH}$ of saliva down to 2.3 , and citrate does not form a complex with zinc ion at such a low pH [130]. However, Zarembo et al. studied the saliva of 18 human subjects, and chewing zinc-citrate lozenges resulted in saliva $\mathrm{pH}$ ranging between 3.2 and 5.0 [144]. Martin calculated that, in the presence of $2 \%$ citric acid in a solution at $\mathrm{pH} 5.1$, only $1.5 \%$ of zinc is in the form of unbound zinc ions, which underscores the problem of complex formation [130].

The solution chemistry of zinc complexes gives further explanations for the variations between the zinc trials. Godfrey et al. [135] administered a particularly high dose of zinc, but glycinate in the lozenge bound 80 to $90 \%$ of the zinc ion to complexes [131-133], which can explain the rather small benefit compared with the other trials using high zinc doses (Table 5). The lozenge of Douglas et al. [141] contained tartaric acid which effectively binds zinc [131,133].

Two controlled trials examined the effect of $23 \mathrm{mg}$ zinc lozenges on experimental rhinovirus colds. Whereas Al-Nakib et al. [145] found significant benefit of the zinc lozenges, Farr et al. found no benefit [146]. The lozenge of Farr contained 2\% citric acid which bound essentially all zinc ions, whereas the lozenge of Al-Nakib did not form complexes of zinc ions, and this difference in the composition of lozenges can explain the divergence in the results [130-133]. Although the solution chemistry calculations of free zinc ion concentrations give further explanations to the variations between trials, the power of dose-response analysis can be seen even by counting the total dosage of zinc (Table 5).

Concluding from Table 5, the benefit of zinc lozenges can be obtained with substantially lower doses than Eby used in the first trial with zinc gluconate lozenges [120]. Four trials used zinc doses in the range of 80 to $90 \mathrm{mg}$ per day and observed significant benefit from the lozenges. Three of these trials used lozenges containing zinc acetate $[136,137,140]$ which does not involve the problem of forming zinc complexes [133].

New trials should confirm the benefit of zinc lozenges in the dose range of 80 to $90 \mathrm{mg}$ per day and examine whether benefit could be obtained with even lower doses with lozenges that do not contain substances that bind zinc ions. With the available evidence, a patient suffering from the common cold can test the effects of zinc lozenges as a personal experimentation.

\section{Safety of zinc}

In the controlled trials zinc lozenges have caused acute adverse effects, such as bad taste. However, none of the common cold trials reported long term harms caused by the zinc lozenges. High dose zinc supplementation, $150 \mathrm{mg} /$ day, has been administered for therapeutic purposes over months and 
years [147-149]. Copper deficiency has been reported as a consequence for some patients because of several years of high-dose zinc supplementation $[148,149]$. However, a six-week study did not find any detrimental effects of $150 \mathrm{mg} /$ day of zinc on plasma copper levels [150]. Consequently, there does not seem to be any reason to assume that treating the common cold for a week with doses that have been used in the zinc lozenge trials might cause unanticipated long term harms. As regards the bad taste and other acute effects, the patient can simply stop taking the lozenge if such discomforts are annoying.

Nasal sprays or gels of zinc have also been studied for treating the common cold and some studies reported benefit. However, several cases of long lasting or permanent anosmia have been reported as a consequence of intranasal zinc administration [151,152]. Given the benign character of the common cold, anosmia is an unacceptable adverse effect. Nasal application of zinc should be discouraged, unless application methods will be developed that do not involve the risk of anosmia.

\section{Reviews on zinc and the common cold}

Given the number of placebo-controlled trials reporting highly significant benefit of zinc lozenges for treating the common cold (Table 5), it is puzzling that some reviews have concluded that there is no evidence that zinc would be beneficial against colds.

Jackson et al. [153,154] searched the literature on zinc and the common cold and found statistically significant heterogeneity between the trials. They calculated a pooled estimate of effect, although firm evidence of heterogeneity introduces serious doubt about the relevance of any one overall estimate. Instead, the main focus should be on trying to understand the sources of heterogeneity [155]. Although Jackson noted that some of the negative results might have been caused by low zinc availability, they did not carry out subgroup analysis by zinc doses. Jackson et al. concluded that their "meta-analysis suggests that the evidence of zinc effectiveness is still lacking" [154], which is based on their inappropriate pooling of the low and high dose trials together.

In their systematic review, Caruso et al. identified 14 zinc trials [156]. They used the quality scoring approach so that for the identified trials they gave one point for each of 11 quality items if it was satisfied. Four of the identified trials reached the maximum of 11 points, two reached 10 points, and eight trials reached 8 points or less. In two tables and one figure, Caruso et al. described the distribution of quality scores and the individual quality features of the trials. They proposed that the positive findings with zinc could be explained by methodological faults.

The approach to evaluate trial quality by a set of explicit criteria was initiated by Chalmers et al. in the early 1980s [157] and thereafter dozens of quality scales have been developed. However, 
the approach was not successful and it is discouraged for example in the Cochrane Handbook, which states that "the use of scales for assessing quality or risk of bias is explicitly discouraged in Cochrane reviews. While the approach offers appealing simplicity, it is not supported by empirical evidence" [158].

One major problem of quality scoring is the focus on reporting in contrast to the scientific quality of the trial. For example, Caruso et al. give one point if there was "measurement of dropout rate" in the trial. This means that a trial can report high dropout rate, which means low scientific quality, yet the trial gets one point from Caruso et al., because the high dropout rate was reported explicitly. Caruso et al. give one point for "sample size calculation" which is important when a trial is planned, because it can show that the planned trial is too small, whereas it is irrelevant after the trial is published, because then the confidence interval reveals the accuracy of the result. Most of Caruso et al.'s remaining nine quality items have similar problems.

Although it is important to consider the methods of a trial, there are no simple criteria which describe that a trial is reliable or not. In a meta-analyses of 276 randomized controlled trial, Balk et al. concluded that "double blinding and allocation concealment, two quality measures that are frequently used in meta-analyses, were not associated with treatment effect" [159] meaning that valid estimates of treatment effect can be reached without them. Furthermore, Glasziou et al. pointed out that firm conclusions of treatment benefit can be drawn even without any control groups [160].

Finally, Caruso et al. did not discuss the possibility that the dose of zinc might have an effect on trial results, nor did they refer to any of the numerous papers that discussed the possibility that the level of free zinc ion might be important [128-133,161].

Thus, the conclusions from Table 5 diverge from the conclusions of two groups of earlier reviewers, but there are reasonable explanations for the divergence in the conclusions. 


\section{Bias against vitamins and minerals}

In the early 1970s, there was academic interest in the effect of vitamin C on the common cold, but then the interest vanished (Fig. 1). The evaporation of interest can be traced to three influential papers published in 1975 [47,70,71]. Although the three papers are severely biased, they have been used singly or as a doublet, for example, as references in nutritional recommendations, in textbooks of medicine, infectious diseases, and nutrition when authors argued that vitamin $\mathrm{C}$ has been shown to be useless for colds [48,69,72-79]. For example, the American Medical Association based its official statement that "One of the most widely misused vitamins is ascorbic acid. There is no reliable evidence that large doses of ascorbic acid prevent colds or shorten their duration" wholly on Chalmers' 1975 review [162, p 1934].

Bias against zinc lozenges is seen, for example, in Caruso et al.'s recent review [156], which focused on methodological features, mostly irrelevant to trial validity, without even presenting the study results. Furthermore, they stated that a "common deficiency [in the zinc trials] was proof of blinding which was lacking in 7 studies. The placebo effect in the treatment of colds was first shown $>70$ years ago and has since been demonstrated in subsequent studies". As a justification for this statement, Caruso et al. referred to the doublet of the Karlowski trial [47] and the Chalmers review [70], although they knew that the two papers were erroneous, because I pointed that out in a criticism of their earlier biased review on echinacea and the common cold $[163,164]$.

Prejudice against nonconventional treatments is not limited to the common cold. Bias against vitamin $\mathrm{C}$ was documented by Richards who compared the attitudes and arguments of physicians to three putative cancer medicines: 5-fluorouracil, interferon, and vitamin C [165-169].

Goodwin and Tangum [170] provided several examples to support the conclusion that there has been systematic bias against the concept that vitamins might be beneficial in levels higher than the minimum required to avoid classic deficiency diseases: "Throughout much of the 20th century, American academic medicine was resistant to the concept that micronutrient supplementation might prove beneficial. This resistance is evident in several ways: (1) by uncritical acceptance of bad news about micronutrient supplements; reports of toxic effects were rarely questioned and widely quoted; (2) by the scornful, dismissive tone of the discussions about micronutrient supplementation in textbooks of medicine, a tone avoided in most medical controversies; and (3) by the sceptical reaction greeting any claim of efficacy of a micronutrient, relative to other therapies; indeed, most claims were simply ignored."

Although the proponents of evidence-based medicine emphasize the primary importance of controlled trials as the source of reliable knowledge of treatment effects, the possibility of 
biologically rationalizing the method usually has a great importance [171]. Goodwin and Goodwin $[172,173]$ reviewed several cases in which an effective method of treatment was erroneously rejected due to a lack of understanding of the physiological mechanism of the effect. They designated this problem 'the tomato effect', since the tomato was considered poisonous in the USA in the 1700s because several other plants in the same family were poisonous: "The tomato effect in medicine occurs when an efficacious treatment for a certain disease is ignored or rejected because it does not 'make sense' in the light of accepted theories of disease mechanism and drug action."

Finally, in a paper discussing great scientific discoveries, Barber [174] noted "Medical experts have a long history of resisting scientific innovations from what they define as 'the outside'." Thus, it is possible that this mechanism is a further reason for prejudices against vitamin $\mathrm{C}$ and zinc in the medical community, as the most active proponents, Pauling and Eby, are not physicians.

Goodwin and Tangum [170] conclude their paper on micronutrient supplements in academic medicine a follows: "There are only 3 important questions when evaluating a potential treatment. Does it work? What are the adverse effects? How much does it cost? Ideally, issues such as the theory underlying the treatment or the guild to which the proponents of the treatment belong should be irrelevant to the fundamental questions of efficacy, toxicity, and cost. The history of the response of academic medicine to micronutrient supplementation suggests that we have not attained that ideal." 


\section{Conclusions}

Regular vitamin $\mathrm{C}$ supplementation reduces common cold symptoms and probably vitamin $\mathrm{C}$ is beneficial when administered therapeutically, starting immediately after the onset of symptoms. However, few therapeutic vitamin $\mathrm{C}$ trials have been published, and none with children although regular vitamin $\mathrm{C}$ has greater effect on children than on adults. In the controlled trials, the largest doses were $6 \mathrm{~g}$ /day for adults and $2 \mathrm{~g}$ /day for children and such doses may be safely tested as a treatment option by common cold patients.

The results of zinc lozenge trials have diverged, but the divergence is explained largely by the variation in dosage, so that doses over $80 \mathrm{mg}$ /day have quite consistently reduced the duration of colds. Zinc lozenges have caused high frequency of adverse effects, such as bad taste, but there is no evidence that zinc lozenges would cause actual long term harm. A large proportion of trial participants remained without adverse effects and consequently zinc lozenges might be useable by them.

Thus, both vitamin $\mathrm{C}$ and zinc supplementation have a potential for becoming options for treating the common cold. Both of them are safe in the doses that have been tested, there is strong evidence that they differ from placebo, they are inexpensive and, unlike the antibiotics [175], they do not cause harms on microbial ecology.

In the case of vitamin $\mathrm{C}$ and zinc, the most reasonable approach would seem to be to test them at the individual level so that the patient decides whether the benefits are worth the cost, the side effects and the involved efforts. This kind of approach is not different from ordinary treatments for acute medical problems in the community. Although a controlled trial can show that an analgesic differs on average from a placebo, it is the patient who decides whether a particular drug is effective for him or her. Thus, experimentation at the individual level may be encouraged, yet simultaneously more research is needed on vitamin $\mathrm{C}$ tablets and zinc lozenges to find out optimal doses and treatment strategies.

Vitamin $\mathrm{C}$ has no prophylactic effect in the general community, but it may reduce the incidence of respiratory symptoms in restricted population groups such as people under heavy acute physical stress and people who have particularly low dietary vitamin $\mathrm{C}$ intake. The effect of vitamin E on the common cold incidence is heterogeneous which means that it is not ineffective over all the population. Nevertheless, further studies are needed to specify the population groups that might possibly benefit from vitamin E supplementation.

Vitamin D and folic acid have been constituents in five multivitamin supplements that have been tested for old people. Those supplements did not prevent respiratory infections implying that 
vitamin D and folic acid do not have substantial preventive effects against respiratory infections. There is no evidence suggesting that $\beta$-carotene would be beneficial against the common cold, whereas it increased mortality in two large-scale trials, and therefore self-supplementation should be discouraged. 


\section{References}

Links to the fulltexts or abstracts of the following reference list that are available via the internet, can be found at: http://www.ltdk.helsinki.fi/users/hemila/birkhauser. Some of the publications are located at the publisher's pages and require permissions to be reached, but several are freely available. The file will be updated so that new controlled trials on the substances discussed in this chapter will be appended at the end of the file.

Mäkelä MJ, Puhakka T, Ruuskanen O, Leinonen M, Saikku P, Kimpimäki M, Blomqvist S, Hyypiä T, Arstila P (1998) Viruses and bacteria in the etiology of the common cold. J Clin Microbiol 36: 539-542 Syrjälä H, Broas M, Suramo I, Ojala A, Lähde S (1998) High resolution computed tomography for the diagnosis of community-acquired pneumonia. Clin Infect Dis 27: 358-363 Millen AE, Dodd KW, Subar AF (2004) Use of vitamin, mineral, nonvitamin, and nonmineral supplements in the United States: The 1987, 1992, and 2000 National Health Interview Survey results. J Am Diet Assoc 104: $942-950$ Pauling L (1971) The significance of the evidence about ascorbic acid and the common cold. Proc Natl Acad Sci USA 68: 2678-2681 Pauling L (1971) Ascorbic acid and the common cold. Am J Clin Nutr 24: 1294-1299 Cowan DW, Diehl HS, Baker AB (1942) Vitamins for the prevention of colds. JAMA 120: 1268-1271 Ritzel G (1961) Kritische Beurteilung des Vitamins C als Prophylacticum und Therapeuticum der Erkältungskrankheiten [Critical analysis of the role of vitamin $\mathrm{C}$ in the treatment of the common cold]. Helv Med Acta 28: 63-68. Translation at: http://www.ltdk.helsinki.fi/users/hemila/T3.pdf (accessed 29 December 2008) Hess AF (1920) Scurvy: Past and Present. Philadelphia, PA: Lippincott. A digitalized version is available at the Cornell University Library: http://chla.library.cornell.edu/ (accessed 29 December 2008) Robertson EC (1934) The vitamins and resistance to infection: vitamin C. Medicine 13: 190-206 712

Bourne GH (1949) Vitamin C and immunity. Br J Nutr 2: 341-347

Glazebrook AJ, Thomson S (1942) The administration of vitamin C in a large institution and its effect on general health and resistance to infection. J Hygiene 42: 1-19

Hemilä H, Louhiala P (2007) Vitamin C may affect lung infections. $J$ R Soc Med 100: 495-498

Hemilä H (2006) Do vitamins $C$ and $E$ affect respiratory infections? [PhD Thesis]. University of Helsinki, Helsinki, Finland, pp. 11-16, 35-51. Available at: http://ethesis.helsinki.fi/julkaisut/laa/kansa/vk/hemila/ (accessed 29 December 2008)

Bartley W, Krebs HA, O'Brien JRP (1953) Vitamin C Requirement of Human Adults. A Report by the Vitamin C Subcommittee of the Accessory Food Factors Committee. Spec Rep Ser Med Res Counc (GB) No. 280. HMSO, London, p. 43 Pauling L (1970) Vitamin C and the Common Cold. San Francisco: Freeman Pauling L (1976) Vitamin C, the Common Cold, and the Flu. San Francisco: Freeman Hemilä H (1992) Vitamin C and the common cold. Br J Nutr 67: 3-16 Himmelstein SA, Robergs RA, Koehler KM, Lewis SL, Qualls CR (1998) Vitamin C supplementation and upper respiratory tract infections in marathon runners. J Exercise Physiology online 1(2; July). Available at: http://faculty.css.edu/tboone2/asep/jan9.htm (accessed 29 December 2008) van Straten M, Josling P (2002) Preventing the common cold with a vitamin C supplement: a double-blind, placebo-controlled survey. Adv Ther 19: 151-159

Hemilä H (1997) Vitamin C intake and susceptibility to the common cold. Br J Nutr 77: 59-72; discussion: 1997;78: 857-866

Briggs M (1984) Vitamin C and infectious disease: a review of the literature and the results of a randomized, double-blind, prospective study over 8 years. In: MH Briggs (ed.) Recent Vitamin Research. CRC Press, Boca Raton, FL, pp 39-82 
cold. Cochrane Database Syst Rev CD000980

Hemilä H (1996) Vitamin C and common cold incidence: a review of studies with subjects under heavy physical stress. Int J Sports Med 17: 379-383

Hemilä H (2004) Vitamin C supplementation and respiratory infections: a systematic review. Mil Med 169: 920-925

Peters EM, Goetzsche JM, Grobbelaar B, Noakes TD (1993) Vitamin C supplementation reduces the incidence of postrace symptoms of upper-respiratory-tract infection in ultramarathon runners. Am J Clin Nutr 57: 170-174

Peters EM, Goetzsche JM, Joseph LE, Noakes TD (1996) Vitamin C as effective as combinations of antioxidant nutrients in reducing symptoms of upper respiratory tract infection in ultramarathon runners. $S$ Afr J Sports Med 11(March): 23-27

Moolla ME (1996) The effect of supplemental anti-oxidants on the incidence and severity of upper respiratory tract infections in ultra-marathon runners [MSc Thesis]. South Africa: University of Cape Town

Sabiston BH, Radomski MW (1974) Health Problems and Vitamin C in Canadian Northern Military Operations. DCIEM Report no. 74-R-1012. Defence and Civil Institute of Environmental Medicine; Downsview, Ontario, Canada. 10 pp. Available at:

http://www.ltdk.helsinki.fi/users/hemila/CC/Sabiston_1974_ch.pdf (accessed 29 December 2008)

in elite athletes. J Allergy Clin Immunol 122: 225-235; discussion: 2008; in press Schachter EN, Schlesinger A (1982) The attenuation of exercise-induced bronchospasm by ascorbic acid. Ann Allergy 49: 146-151 Cohen HA, Neuman I, Nahum H (1997) Blocking effect of vitamin C in exercise-induced asthma. Arch Pediatr Adolesc Med 151: 367-370 Tecklenburg SL, Mickleborough TD, Fly AD, Bai Y, Stager JM (2007) Ascorbic acid supplementation attenuates exercise-induced bronchoconstriction in patients with asthma. Resp Med 101: 1770-1778 Charleston SS, Clegg KM (1972) Ascorbic acid and the common cold. Lancet 299: 1401-1402 Clegg KM, Macdonald JM (1975) L-ascorbic acid and D-isoascorbic acid in a common cold survey. Am J Clin Nutr 28: 973-976 the prevention and amelioration of the common cold. Br J Prev Soc Med 30: 193-196 Baird IM, Hughes RE, Wilson HK, Davies JE, Howard AN (1979) The effects of ascorbic acid and flavonoids on the occurrence of symptoms normally associated with the common cold. Am J Clin Nutr 32: 1686-1690 Tyrrell DAJ, Craig JW, Meade TW, White T (1977) A trial of ascorbic acid in the treatment of the common cold. Br J Prev Soc Med 31: 189-191 Hemilä H (2008) Vitamin C and sex differences in respiratory tract infections. Resp Med 102: 625-626 Anderson TW, Reid DBW, Beaton GH (1972) Vitamin C and the common cold: a double-blind trial. Can Med Assoc J 107: 503-508; corrections: 1973;108: 133 and 1973;108: 492 Anderson TW, Beaton GH, Corey PN, Spero L (1975) Winter illness and vitamin C: the effect of relatively low doses. Can Med Assoc J 112: 823-826 in children. Scand J Infect Dis 9: 91-98 Hemilä H (1999) Vitamin C supplementation and common cold symptoms: factors affecting the magnitude of the benefit. Med Hypotheses 52: 171-178 Coulehan JL, Reisinger KS, Rogers KD, Bradley DW (1974) Vitamin C prophylaxis in a boarding school. $N$ Engl J Med 290: 6-10 respiratorias agudas del escolar [Prophylactic value of vitamin $\mathrm{C}$ in acute respiratory infections of schoolchildren]. Rev Med Chil 112: 871-876. Translation at: http://www.ltdk.helsinki.fi/users/hemila/T6.pdf (accessed 29 December 2008) Karlowski TR, Chalmers TC, Frenkel
common cold. JAMA 231: 1038-1042 Hemilä H (1996) Vitamin C, the placebo effect, and the common cold: a case study of how preconceptions influence the analysis of results. J Clin Epidemiol 49: 1079-1084 Hemilä H (1997) Vitamin C supplementation and the common cold: was Linus Pauling right or wrong? Int J Vitam Nutr Res 67: 329-335 Anderson TW, Suranyi G, Beaton GH (1974) The effect on winter illness of large doses of vitamin C. Can Med Assoc J 111: 31-36 
pharmacokinetics: implications for oral and intravenous use. Ann Intern Med 140: 533-537

Padayatty SJ, Riordan HD, Hewitt SM, Katz A, Hoffer LJ, Levine M (2006) Intravenously administered

vitamin C as cancer therapy: three cases. CMAJ 174: 937-942

Rivers JM (1987) Safety of high-level vitamin C ingestion. Ann NY Acad Sci 498: 445-454

Hathcock JN, Azzi A, Blumberg J, Bray T, Dickinson A, Frei B, Jialal I, Johnston CS, Kelly FJ, Kraemer

$\mathrm{K}$, et al. (2005) Vitamins $\mathrm{E}$ and $\mathrm{C}$ are safe across a broad range of intakes. Am J Clin Nutr 81: 736-745

Gotzsche AL (1989). Pernasal vitamin C and the common cold. Lancet 2: 1039

Beisel WR (1982) Single nutrients and immunity: vitamin C. Am J Clin Nutr 35(Feb suppl): 423-428, 460461

Gross RL, Newberne PM (1980) Role of nutrition in immunologic function: vitamin C. Physiol Rev 60: 255-260, 290-302

Jariwalla RJ, Harakeh S (1996) Antiviral and immunomodulatory activities of ascorbic acid. Subcell Biochem 25: 215-231

Webb AL, Villamor E (2007) Effects of antioxidant and non-antioxidant vitamin supplementation on immune function. Nutr Rev 65: 181-217

Akaike T, Noguchi Y, Ijiri S, Setoguchi K, Suga M, Zheng YM, Dietzschold B, Maeda H (1996)

Pathogenesis of influenza virus-induced pneumonia: involvement of both nitric oxide and oxygen radicals. Proc Natl Acad Sci USA 93: 2448-2453 Akaike T (2001) Role of free radicals in viral pathogenesis and mutation. Rev Med Virol 11: 87-101

Snelgrove RJ, Edwards L, Rae AJ, Hussell T (2006) An absence of r
resolution of lung influenza infection. Eur J Immunol 36: 1364-1273

Castro SM, Guerrero-Plata A, Suarez-Real G, Adegboyega PA, Colasurdo GN, Khan AM, Garofalo RP Casola A (2006) Antioxidant treatment ameliorates respiratory syncytial virus-induced disease and lung inflammation. Am J Respir Crit Care Med 174: 1361-1369

Hemilä H (2006) Do vitamins $C$ and $E$ affect respiratory infections? [PhD Thesis]. Helsinki, Finland:

University of Helsinki; pp. 5-10, 105-131. Available at:

http://ethesis.helsinki.fi/julkaisut/laa/kansa/vk/hemila/ (accessed 29 December 2008)

of antioxidant manipulation. J Nutr 122: 766-773

Packer L (1997) Oxidants, antioxidant nutrients and the athlete. J Sports Sci 15: 353-363 reviews. Nutrition 12: 804-809

Chalmers TC (1975) Effects of ascorbic acid on the common cold: an evaluation of the evidence. Am J Med 58: $532-536$

Dykes MHM, Meier P
JAMA 231: 1073-1079

Hemilä H, Herman ZS (1995) Vitamin C and the common cold: a retrospective analysis of Chalmers' review. J Am Coll Nutr 14: 116-123

Hemilä H (2008) Chalmers' meta-analysis 1975. Available at:

http://www.ltdk.helsinki.fi/users/hemila/reviews/chalmers (accessed 29 December 2008)

Hemilä H (2008) The Dykes and Meier review 1975. Available at:

http://www.ltdk.helsinki.fi/users/hemila/reviews/dykes (accessed 29 December 2008)

Pauling L (1976) Ascorbic acid and the common cold: evaluation of its efficacy and toxicity. Part I. Medical Tribune 17(12): 18-19

Pauling L (1976) Ascorbic acid and the common cold. Part II. Medical Tribune 17(13): 37-38

Chalmers TC (1996) Dissent to the preceding article by H. Hemilä. J Clin Epidemiol 49: 1085

Hemilä H (1996) To the dissent by Thomas Chalmers. J Clin Epidemiol 49: 1087

Hemilä H (2008) The most influential trial on vitamin C and the common cold: Karlowski et al. 1975.

Available at: http://www.ltdk.helsinki.fi/users/hemila/karlowski (accessed 29 December 2008)

Truswell AS (1986) Ascorbic acid [letter]. N Engl J Med 315: 709

Kleijnen J, Riet G, Knipschild PG (1989) Vitamine C en verkoudheid; overzicht van een megadosis literatuur [in Dutch; Vitamin C and the common cold; a review of the megadose literature]. Ned Tijdschr Geneeskd 133: 1532-1535 
Hemilä H (2008) Pauling's meta-analyses 1971a,b. Available at:

http://www.ltdk.helsinki.fi/users/hemila/reviews/pauling (accessed 29 December 2008)

Meydani SN, Wu D, Santos MS, Hayek MG (1995) Antioxidants and immune response in aged persons: overview of present evidence. Am J Clin Nutr 62: 1462S-1476S

Moriguchi S, Muraga M (2000) Vitamin E and immunity. Vitam Horm 59: 305-336

Baehner RL, Boxer LA, Allen JM, Davis J (1977) Autoxidation as a basis for altered function by polymorphonuclear leukocytes. Blood 50: 327-335 Prasad JS (1980) Effect of vitamin E supplementation on leukocyte function. Am J Clin Nutr 33: 606-608 Eckman JR, Eaton JW, Berger E, Jacob HS (1976) Role of vitamin E in regulating malaria expression. Transact Assoc Am Physicians 89: 105-115

Taylor DW, Levander OA, Krishna VR, Evans CB, Morris VC, Barta JR (1997) Vitamin E-deficient diets enriched with fish oil suppress lethal Plasmodium yoelii infections in athymic and scid/bg mice. Infect Immun 65: 197-202

Garg R, Singh N, Dube A (2004) Intake of nutrient supplements affects multiplication of Leishmania donovani in hamsters. Parasitology 129: 685-691

Graat JM, Schouten EG, Kok FJ (2002) Effects of daily vitamin E and multivitamin-mineral supplementation on acute respiratory tract infections in elderly persons: a randomized controlled trial. JAMA 288: 715-721 Meydani SN, Leka LS, Fine BC, Dallal GE, Keusch GT, Singh MF, Hamer DH (2004) Vitamin E and respiratory tract infections in elderly nursing home residents: a randomized controlled trial. JAMA 292: 828-836; corrections: 2004;292: 1305 and 2007;297: 1882; discussion: 2004;292: 2834 Hemilä H (2005) Potential harm of vitamin E supplementation. Am J Clin Nutr 82: 1141-1142 Hamer DH, Meydani SN (2004) Vitamin E and respiratory tract infections in elderly people. JAMA 292: 2834 The Alpha-Tocopherol, Beta-Carotene Cancer Prevention Study Group (1994) The effect of vitamin E and beta-carotene on the incidence of lung cancer and other cancers in male smokers. N Engl J Med 330: 10291035

Hemilä H, Kaprio J, Albanes D, Heinonen OP, Virtamo J (2002) Vitamin C, vitamin E, and beta-carotene in relation to common cold incidence in male smokers. Epidemiology 3: 32-37 Hemilä H, Virtamo J, Albanes D, Kaprio J (2006) The effect of vitamin E on common cold incidence is modified by age, smoking and residential neighborhood. J Am Coll Nutr 25: 332-339 Hemilä H, Virtamo J, Albanes D, Kaprio J (2004) Vitamin E and beta-carotene supplementation and hospital-treated pneumonia incidence in male smokers. Chest 125: 557-565 Hemilä H, Virtamo J, Albanes D, Kaprio J (2003) Physical activity and the common cold in men administered vitamin E and $\beta$-carotene. Med Sci Sports Exerc 35: 1815-1820

101 Hemilä H, Kaprio J, Albanes D, Virtamo J (2006) Physical activity and the risk of pneumonia in men administered vitamin E and $\beta$-carotene. Int J Sports Med 27: 336-341 Bendich A (1989) Carotenoids and the immune response. J Nutr 119: 112-115 Hughes DA (1999) Effects of carotenoids on human immune function. Proc Nutr Soc 58: 713-718

Health 19: 73-99 infection in elderly subjects. Lancet 340: 1124-1127

\section{7-2248}

107 White C (2004) Three journals raise doubts on validity of Canadian studies. BMJ 328: 67; correction: 2004;328: 257

108 Smith R (2005) Investigating the previous studies of a fraudulent author. BMJ 331: 288-291

109 Chavance M, Herbeth B, Lemoine A, Zhu BP (1993) Does multivitamin supplementation prevent infections in healthy elderly subjects? A controlled trial. Int J Vitam Nutr Res 63: 11-16

110 Girodon F, Lombard M, Galan P, Brunet-Lecomte P, Monget AL, Arnaud J, Preziosi P, Hercberg S (1997) Effect of micronutrient supplementation on infection in institutionalized elderly subjects. Ann Nutr Metab 41: $98-107$

111 Girodon F, Galan P, Monget AL, Boutron-Ruault MC, Brunet-Lecomte P, Preziosi P, Arnaud J, Manuguerra JC, Hercberg S (1999) Impact of trace elements and vitamin supplementation on immunity and infections in institutionalized elderly patients. Arch Intern Med 159: 748-754

112 Barringer TA, Kirk JK, Santaniello AC, Foley KL, Michielutte R (2003) Effect of multivitamin and mineral supplement on infection and quality of life. Ann Intern Med 138: 365-371

113 Avenell A, Campbell MK, Cook JA, Hannaford PC, Kilonzo MM, McNeill G, Milne AC, Ramsay CR, Seymour DG, Stephen AI, et al. (2005) Effect of multivitamin and multimineral supplements on morbidity 
from infections in older people (MAVIS trial): pragmatic, randomised, double blind, placebo controlled trial. $B M J$ 331: 324-329

114 Liu BA, McGeer A, McArthur MA, Simor AE, Aghdassi E, Davis L, Allard JP (2007) Effect of multivitamin and mineral supplementation on episodes of infection in nursing home residents: a randomized, placebo-controlled study. J Am Geriatr Soc 55: 35-42; correction: 2007;55: 478; discussion: 2007;55: 1311-1314

115 Fischer Walker C, Black RE (2004) Zinc and the risk for infectious disease. Annu Rev Nutr 24: 255-275

116 Aggarwal R, Sentz J, Miller MA (2007) Role of zinc administration in prevention of childhood diarrhea and respiratory illnesses: a meta-analysis. Pediatrics 119: 1120-1130

117 Coles CL, Bose A, Moses PD, Mathew L, Agarwal I, Mammen T, Santosham M (2007) Infectious etiology modifies the treatment effect of zinc in severe pneumonia. Am J Clin Nutr 86: 397-403

118 Kurugöl Z, Akilli M, Bayram N, Koturoglu G (2006) The prophylactic and therapeutic effectiveness of zinc sulphate on common cold in children. Acta Paediatr 95: 1175-1181

119 Kurugöl Z, Bayram N, Atik T (2007) Effect of zinc sulfate on common cold in children: randomized, double blind study. Pediatr Int 49: 842-847

120 Eby GA, Davis DR, Halcomb WW (1984) Reduction in duration of common cold by zinc gluconate lozenges in a double-blind study. Antimicrob Agents Chemother 25: 20-24

Prasad AS (2008) Zinc in human health: effect of zinc on immune cells. Mol Med 14: 353-357

Korant BD, Butterworth BE (1976) Inhibition by zinc of rhinovirus protein cleavage: interaction of zinc with capsid polypeptides. $J$ Virol 18: 298-306

123 Geist FC, Bateman JA, Hayden FG (1987) In vitro activity of zinc salts against human rhinoviruses. Antimicrob Agents Chemother 31: 622-624

124 Suara RO, Crowe JE (2004) Effect of zinc salts on respiratory syncytial virus replication. Antimicrob Agents Chemother 48: 783-790

125 Berg K, Bolt G, Andersen H, Owen TC (2001) Zinc potentiates the antiviral action of human IFN-alpha tenfold. J Interferon Cytokine Res 21: 471-474

126 Novick SG, Godfrey JC, Godfrey NJ, Wilder HR (1996) How does zinc modify the common cold? Clinical observations and implications regarding mechanisms of action. Med Hypotheses 46: 295-302

127 Novick SG, Godfrey JC, Pollack RL, Wilder HR (1997) Zinc-induced suppression of inflammation in the respiratory tract, caused by infection with human rhinovirus and other irritants. Med Hypotheses 49: 347357

Godfrey JC (1988) Zinc for the common cold. Antimicrob Agents Chemother 32: 605-606

129 Eby GA (1988) Stability constants of zinc complexes affect common cold treatment results. Antimicrob Agents Chemother 32: 606-607

130 Martin RB (1988) $\mathrm{pH}$ as a variable in free zinc ion concentration from zinc-containing lozenges. Antimicrob Agents Chemother 32: 608-609

131 Eby GA (1997) Zinc ion availability - the determinant of efficacy in zinc lozenge treatment of common colds. J Antimicrob Chemother 40: 483-493

132 Bakar NKA, Taylor DM, Williams DR (1999) The chemical speciation of zinc in human saliva: possible correlation with reduction of the symptoms of the common cold produced by zinc gluconate-containing lozenges. Chemical Speciation and Bioavailability 11: 95-101

133 Eby GA (2004) Zinc lozenges: cold cure or candy? Solution chemistry determinations. Biosci Rep 24: 23-39

134 Smith DS, Helzner EC, Nuttall CE, Collins M, Rofman BA, Ginsberg D, Goswick CB, Magner A (1989) Failure of zinc gluconate in treatment of acute upper respiratory tract infections. Antimicrob Agents Chemother 33: 646-648

135 Godfrey JC, Conant-Sloane B, Smith DS, Turco JH, Mercer N, Godfrey NJ (1992) Zinc gluconate and the common cold: a controlled clinical study. J Int Med Res 20: 234-246

136 Prasad AS, Fitzgerald JT, Bao B, Beck FW, Chandrasekar PH (2008) Duration and severity of symptoms and levels of plasma interleukin-1 receptor antagonist, soluble tumor necrosis factor receptor, and adhesion molecules in patients with common cold treated with zinc acetate. J Infect Dis 197: 795-802

137 Petrus EJ, Lawson KA, Bucci LR, Blum K (1998) Randomized, double-masked, placebo-controlled clinical study of the effectiveness of zinc acetate lozenges on common cold symptoms in allergy-tested subjects. Curr Ther Res 59: 595-607

138 Turner RB, Cetnarowski WE (2000) Effect of treatment with zinc gluconate or zinc acetate on experimental and natural colds. Clin Infect Dis 31: 1202-1208; discussion in: 2001;32: 1520

139 Mossad SB, Macknin ML, Medendorp SV, Mason P (1996) Zinc gluconate lozenges for treating the common cold: a randomized, double-blind, placebo-controlled study. Ann Intern Med 125: 81-88

140 Prasad AS, Fitzgerald JT, Bao B, Beck FW, Chandrasekar PH (2000) Duration of symptoms and plasma cytokine levels in patients with the common cold treated with zinc acetate; a randomized, double-blind, placebo-controlled trial. Ann Intern Med 133: 245-252 
Douglas RM, Miles HB, Moore BW, Ryan P, Pinnock CB (1987) Failure of effervescent zinc acetate lozenges to alter the course of upper respiratory infection in Australian adults. Antimicrob Agents Chemother 31: 1183-1187

142 Macknin ML, Piedmonte M, Calendine C, Janosky J, Wald E (1998) Zinc gluconate lozenges for treating the common cold in children: a randomized controlled trial. JAMA 279: 1962-1967

143 Weismann K, Jakobsen JP, Weismann JE, Hammer UM, Nyholm SM, Hansen B, Lomholt KE, Schmidt K (1990) Zinc gluconate lozenges for common cold: a double-blind clinical trial. Dan Med Bull 37: 279-281

144 Zarembo JE, Godfrey JC, Godfrey NJ (1992) Zinc(II) in saliva: determination of concentrations produced by different formulations of zinc gluconate lozenges containing common excipients. J Pharm Sci 81: 128-130 Al-Nakib W, Higgins PG, Barrow I, Batstone G, Tyrrell DA (1987) Prophylaxis and treatment of rhinovirus colds with zinc gluconate lozenges. J Antimicrob Chemother 20: 893-901

146 Farr BM, Conner EM, Betts RF, Oleske J, Minnefor A, Gwaltney JM (1987) Two randomized controlled trials of zinc gluconate lozenge therapy of experimentally induced rhinovirus colds. Antimicrob Agents Chemother 31: 1183-1187

147 Simkin PA (1976) Oral zinc sulphate in rheumatoid arthritis. Lancet 2: 539-542

148 Prasad AS, Brewer GJ, Schoomaker EB, Rabbani P (1978) Hypocupremia induced by zinc therapy in adults. JAMA 240: 2166-2168

149 Hoffman HN, Phyliky RL, Fleming CR (1988) Zinc-induced copper deficiency. Gastroenterology 94: 508512

150 Samman S, Roberts DC (1987) The effect of zinc supplements on plasma zinc and copper levels and the reported symptoms in healthy volunteers. Med J Aust 146: 246-249

Jafek BW, Linschoten MR, Murrow BW (2004) Anosmia after intranasal zinc gluconate use. Am J Rhinol 18: $137-141$

152 Alexander TH, Davidson TM (2006). Intranasal zinc and anosmia: the zinc-induced anosmia syndrome. Laryngoscope 116: 217-220; discussion: 2006;116: 1720-1723

153 Jackson JL, Peterson C, Lesho E (1997) A meta-analysis of zinc salts lozenges and the common cold. Arch Intern Med 157: 2373-2376

154 Jackson JL, Lesho E, Peterson C (2000) Zinc and the common cold: a meta-analysis revisited. J Nutr 130(5S Suppl): 1512S-1515S

155 Thompson SG (1994) Why sources of heterogeneity in meta-analysis should be investigated. BMJ 309: 1351-1355

156 Caruso TJ, Prober CG, Gwaltney JM (2007) Treatment of naturally acquired common colds with zinc: a structured review. . Clin Infect Dis 45: 569-574

157 Chalmers TC, Smith H, Blackburn B, Silverman B, Schroeder B, Reitman D, Ambroz A (1981) A method for assessing the quality of a randomized control trial. Control Clin Trials 2: 31-49

158 Higgins JPT, Green S (eds.). (2008) Cochrane Handbook for Systematic Reviews of Interventions Version 5.0.1 [updated September 2008]. Section 8.3.3. The Cochrane Collaboration. Available at: www.cochranehandbook.org (accessed 29 December 2008)

Balk EM, Bonis PA, Moskowitz H, Schmid CH, Ioannidis JP, Wang C, Lau J (2002) Correlation of quality measures with estimates of treatment effect in meta-analyses of randomized controlled trials. JAMA 287: 2973-2982

160 Glasziou P, Chalmers I, Rawlins M, McCulloch P (2007) When are randomised trials unnecessary? Picking signal from noise. BMJ 334: 349-351

161 Eby GA (2008) Therapeutic effectiveness of ionic zinc for common colds [letter]. Clin Infect Dis 46: 483484

162 Council of Scientific Affairs, American Medical Association (1987) Vitamin preparations as dietary supplements and as therapeutic agents. JAMA 257: 1929-1936

163 Caruso TJ, Gwaltney JM (2005) Treatment of the common cold with echinacea: a structured review. Clin Infect Dis 40: 807-810

164 Hemilä H (2005) Echinacea, vitamin C, the common cold, and blinding [letter]. Clin Infect Dis 41: $762-763$

165 Richards E (1988) The politics of therapeutic evaluation: the vitamin C and cancer controversy. Soc Stud Sci 18: 653-701

166 Richards E (1991) Vitamin C and Cancer: Medicine or Politics? NY: St Martins Press

167 Galloway J (1991) Crusades and rackets [book review]. Nature 353: 125

168 Segerstråle U (1992) Vitamin C and cancer - medicine or politics [book review]. Science 255: 613-615

169 Huxtable RJ (1992) C for controversy [book review]. Trends Pharmacol Sci 13: 82-83

170 Goodwin JS, Tangum MR (1998) Battling quackery: attitudes about micronutrient supplements in American Academic medicine. Arch Intern Med 158: 2187-2191

171 Vandenbroucke JP, de Craen AJM (2001) Alternative medicine: a mirror image for scientific reasoning in conventional medicine. Ann Intern Med 135: 507-513 
Goodwin JS, Goodwin JM (1981) Failure to recognize efficacious treatments: a history of salicylate therapy in rheumatoid arthritis. Persp Biol Med 31: 78-92

173 Goodwin JS, Goodwin JM (1984) The tomato effect: rejection of highly efficacious therapies. JAMA 251: 2387-2390

174 Barber B (1961) Resistance by scientists to scientific discovery. Science 134: 596-602

175 Gonzales R, Sande M (1995) What will it take to stop physicians from prescribing antibiotics in acute bronchitis? Lancet 345: 665-666 
Table 1: Heterogeneity in the vitamin C effect on the common cold: Anderson et al. trials of 1972 and 1975

\begin{tabular}{|c|c|c|}
\hline Subgroup & \multicolumn{2}{|c|}{$\begin{array}{c}\text { Effect on the "total days } \\
\text { indoors" per person }\end{array}$} \\
\hline & $\begin{array}{c}\text { Regular } \\
\text { supplement } \\
1972-\text {-study }\end{array}$ & $\begin{array}{c}\text { Therapeutic } \\
\text { supplement } \\
1975 \text {-study }\end{array}$ \\
\hline Daily juice & & \\
\hline $0-3 \mathrm{oz}$ & $-48 \%$ & $-33 \%$ \\
\hline$\geq 4 \mathrm{oz}$ & $-22 \%$ & $-22 \%$ \\
\hline Contact with \\
young children & & \\
\hline Yes & $-46 \%$ & $-40 \%$ \\
\hline No & $-17 \%$ & $-13 \%$ \\
\hline Frequently in & & \\
\hline crowds & & $-25 \%$ \\
\hline Yes & $-34 \%$ & $-29 \%$ \\
\hline No & $-17 \%$ & \\
\hline Usual colds: & & \\
\hline$\geq 2$ & $-43 \%$ & \\
\hline $0-1$ & $-13 \%$ & \\
\hline
\end{tabular}

${ }^{a}$ Anderson et al. 1972 [41]: $1 \mathrm{~g} /$ day vitamin C was administered regularly and $3 \mathrm{~g} /$ day extra was administered during a cold episode for three days. For all participants, the effect of vitamin $\mathrm{C}$ on "total days indoors" per person was reduced by $30 \%(\mathrm{P}=0.001)$ suggesting that there may be sufficient statistical power to explore subgroup differences, but the authors did not test the significance of the interactions. Based on Anderson's table IV.

${ }^{\mathrm{b}}$ Anderson et al. 1975 [42] administered $1.5 \mathrm{~g}$ /day vitamin $\mathrm{C}$ on the first day of the cold and thereafter $1 \mathrm{~g} /$ day for a total of 5 days. For all participants, the effect of vitamin $\mathrm{C}$ on "total days indoors" per person was reduced by $25 \%(\mathrm{P}=0.046)$. Based on Anderson's table III. 
Table 2: Vitamin E and common cold incidence:

modification of the effect by age and the level of smoking:

the ATBC Study 1985-1993

\begin{tabular}{|c|c|c|c|c|}
\hline $\begin{array}{c}\text { Age group } \\
\text { Cigarettes } \\
\text { per day }\end{array}$ & Visits & $\begin{array}{l}\text { Colds per visit } \\
\text { Vit E/Placebo }\end{array}$ & $\begin{array}{c}\text { RR } \\
95 \% \mathrm{CI})\end{array}$ & $\begin{array}{c}\text { Test of } \\
\text { interaction } \\
\text { P-value }\end{array}$ \\
\hline \multicolumn{5}{|l|}{$50-54$ yr } \\
\hline $5-14$ & 4,972 & $0.340 / 0.289$ & $\begin{array}{c}1.18 \\
(1.06-1.30)\end{array}$ & \multirow{2}{*}{0.001} \\
\hline$\geq 15$ & 28,742 & $0.323 / 0.330$ & $\begin{array}{c}0.98 \\
(0.94-1.02)\end{array}$ & \\
\hline \multicolumn{5}{|l|}{ 63-66 yr } \\
\hline 5-14 & 8,819 & $0.255 / 0.259$ & $\begin{array}{c}0.98 \\
(0.90-1.07)\end{array}$ & \multirow{2}{*}{0.7} \\
\hline$\geq 15$ & 28,467 & $0.241 / 0.241$ & $\begin{array}{c}1.00 \\
(0.95-1.05)\end{array}$ & \\
\hline \multicolumn{5}{|l|}{$\geq 69 \mathrm{yr}$} \\
\hline $5-14$ & 4,755 & $0.193 / 0.260$ & $\begin{array}{c}0.74 \\
(0.65-0.84)\end{array}$ & \multirow{2}{*}{0.00000001} \\
\hline$\geq 15$ & 10,286 & $0.236 / 0.206$ & $\begin{array}{c}1.14 \\
(1.05-1.24)\end{array}$ & \\
\hline
\end{tabular}

Abbreviations: $\mathrm{RR}$, risk ratio; $\mathrm{CI}$, confidence interval.

In the ATBC Study, there were three follow-up visits per year so that the annual common cold incidence is three times the average per visit. For methods, see [98]. 
Table 3: $\beta$-Carotene and common cold incidence: modification of the effect by age and the level of smoking: the ATBC Study 1985-1993

\begin{tabular}{|c|c|c|c|c|}
\hline $\begin{array}{c}\text { Age group } \\
\text { Cigarettes } \\
\text { per day }\end{array}$ & \begin{tabular}{|l|} 
Visits \\
in group
\end{tabular} & $\begin{array}{l}\text { Colds per visit } \\
\beta \text {-Carot/Placebo }\end{array}$ & $\begin{array}{c}\text { RR } \\
(95 \% \mathrm{CI})\end{array}$ & \begin{tabular}{|c|} 
Test of \\
interaction \\
P-value
\end{tabular} \\
\hline \multicolumn{5}{|l|}{$50-53$ yr } \\
\hline \begin{tabular}{|c|}
$5-14$ \\
\end{tabular} & 3,038 & $0.354 / 0.301$ & $\begin{array}{c}1.17 \\
(1.04-1.33)\end{array}$ & \multirow{2}{*}{0.002} \\
\hline$\geq 15$ & 18,528 & $0.324 / 0.344$ & $\begin{array}{c}0.94 \\
(0.90-0.99) \\
\end{array}$ & \\
\hline \multicolumn{5}{|l|}{ 58-67 yr } \\
\hline $5-14$ & 23,941 & $0.255 / 0.253$ & $\begin{array}{c}1.01 \\
(0.96-1.06)\end{array}$ & \multirow{2}{*}{0.9} \\
\hline$\geq 15$ & 85,820 & $0.260 / 0.259$ & $\begin{array}{c}1.00 \\
(0.98-1.03) \\
\end{array}$ & \\
\hline \multicolumn{5}{|l|}{$\geq 70$ yr } \\
\hline $5-14$ & 3,475 & $0.223 / 0.251$ & $\begin{array}{c}0.89 \\
(0.77-1.02) \\
\end{array}$ & \multirow{2}{*}{0.008} \\
\hline$\geq 15$ & 6,993 & $0.217 / 0.193$ & $\begin{array}{c}1.12 \\
(1.01-1.25)\end{array}$ & \\
\hline
\end{tabular}

Abbreviations: RR, risk ratio; $\mathrm{CI}$, confidence interval.

In the ATBC Study, there were three follow-up visits per year so that the annual common cold incidence is three times the average per visit. For methods, see [98]. 
Table 4: Multivitamins and multiminerals for respiratory infections

\begin{tabular}{|c|c|c|c|c|}
\hline \multirow[t]{2}{*}{\begin{tabular}{|l|} 
Study [ref.] \\
Age, Duration of study
\end{tabular}} & \multicolumn{2}{|c|}{\begin{tabular}{|c|} 
No.of episodes \\
/ No.of participants
\end{tabular}} & \multirow[t]{2}{*}{$\begin{array}{c}\mathrm{RR} \\
(95 \% \mathrm{CI})^{\mathrm{b}}\end{array}$} & \multirow[t]{2}{*}{$\begin{array}{l}\text { Outcome } \\
\text { / Subgroup }\end{array}$} \\
\hline & Treatment & \begin{tabular}{|l|} 
Placebo \\
\end{tabular} & & \\
\hline \multicolumn{5}{|l|}{$\begin{array}{l}\text { Chavance } 1993[109] \\
\geq 60 \text { yr, } 4 \text { months }\end{array}$} \\
\hline \begin{tabular}{|c|} 
vit $\mathrm{C} 90 \mathrm{mg}$ \\
vit $\mathrm{E} 30 \mathrm{mg}$ \\
$\mathrm{Zn} 22 \mathrm{mg}$ \\
+18 others
\end{tabular} & $61 / 103$ & $42 / 101$ & $\begin{array}{c}1.42 \\
(0.96-2.11)\end{array}$ & Infections $^{c}$ \\
\hline \multicolumn{5}{|l|}{$\begin{array}{l}\text { Girodon } 1997[110] \\
\geq 65 \mathrm{yr}, 2 \mathrm{yr}\end{array}$} \\
\hline \begin{tabular}{|c|} 
vit C $120 \mathrm{mg}$ \\
vit E $15 \mathrm{mg}$ \\
$\beta$-carotene $6 \mathrm{mg}$ \\
\end{tabular} & $47 / 41$ & $47 / 40$ & $\begin{array}{c}0.98 \\
(0.65-1.46)\end{array}$ & Infections $^{d}$ \\
\hline \begin{tabular}{|l|} 
Zn $20 \mathrm{mg}$ \\
Se $0.1 \mathrm{mg}$ \\
\end{tabular} & $35 / 41$ & $59 / 40$ & $\begin{array}{c}0.58 \\
(0.30-0.88) \\
\end{array}$ & Infections $^{d}$ \\
\hline \multicolumn{5}{|l|}{$\begin{array}{l}\text { Girodon } 1999[111] \\
\geq 65 \mathrm{yr}, 2 \mathrm{yr}\end{array}$} \\
\hline $\begin{array}{c}\text { vit C } 120 \mathrm{mg} \\
\text { vit E } 15 \mathrm{mg} \\
\beta \text {-carotene } 6 \mathrm{mg}\end{array}$ & $229 / 361$ & $239 / 364$ & $\begin{array}{c}0.97 \\
(0.80-1.16)\end{array}$ & $\begin{array}{l}\text { Respiratory } \\
\text { infections }\end{array}$ \\
\hline $\begin{array}{l}\text { Zn } 20 \mathrm{mg} \\
\text { Se } 0.1 \mathrm{mg}\end{array}$ & $223 / 363$ & $245 / 362$ & $\begin{array}{c}0.92 \\
(0.76-1.10)\end{array}$ & $\begin{array}{l}\text { Respiratory } \\
\text { infections }{ }^{\mathrm{e}}\end{array}$ \\
\hline \multicolumn{5}{|l|}{\begin{tabular}{|l|} 
Graat $2002[92]$ \\
$\geq 60 \mathrm{yr}, 1.25 \mathrm{yr}$ \\
\end{tabular}} \\
\hline \begin{tabular}{|c|} 
vit C $60 \mathrm{mg}$ \\
vit E $10 \mathrm{mg}$ \\
$\beta$-carotene $1.2 \mathrm{mg}$ \\
$\mathrm{Zn} 10 \mathrm{mg}$ \\
Se $0.025 \mathrm{mg}$ \\
+21 others \\
\end{tabular} & $514 / 335$ & $510 / 317$ & $\begin{array}{c}0.95 \\
(0.84-1.07)\end{array}$ & $\begin{array}{l}\text { Acute } \\
\text { respiratory } \\
\text { infections } f\end{array}$ \\
\hline \multicolumn{5}{|l|}{$\begin{array}{l}\text { Barringer } 2003[112] \\
\geq 45 \mathrm{yr}, 1 \mathrm{yr} \\
\end{array}$} \\
\hline \multirow{2}{*}{$\begin{array}{c}\text { vit C } 120 \mathrm{mg} \\
\text { vit E } 60 \mathrm{mg} \\
\beta \text {-carotene } 6 \mathrm{mg} \\
\mathrm{Zn} 22 \mathrm{mg} \\
\text { Se } 0.1 \mathrm{mg} \\
+18 \text { others }\end{array}$} & $23 / 39$ & $24 / 40$ & $\begin{array}{c}0.98 \\
(0.68-1.41)\end{array}$ & $\begin{array}{c}\text { Participants } \\
\text { with infections }{ }^{\mathrm{g}} \\
\text { / Not diabetic } \\
\end{array}$ \\
\hline & $4 / 24$ & $25 / 27$ & $\begin{array}{c}0.18 \\
(0.07-0.44)\end{array}$ & $\begin{array}{c}\text { Participants } \\
\text { with infections } \\
\text { / DM type II }\end{array}$ \\
\hline \multicolumn{5}{|l|}{$\begin{array}{l}\text { Avenell } 2005 \text { [113] } \\
\geq 65 \mathrm{yr}, 1 \mathrm{yr}\end{array}$} \\
\hline \begin{tabular}{|c|} 
vit C $60 \mathrm{mg}$ \\
vit $\mathrm{E} 10 \mathrm{mg}$ \\
$\mathrm{Zn} 15 \mathrm{mg}$ \\
+13 others \\
\end{tabular} & $879 / 456$ & $930 / 454$ & $\begin{array}{c}0.94 \\
(0.86-1.03)\end{array}$ & $\begin{array}{l}\text { Contact with } \\
\text { primary care } \\
\text { for infections }\end{array}$ \\
\hline \multicolumn{5}{|l|}{$\begin{array}{l}\text { Liu } 2007[114] \\
\geq 65 \mathrm{yr}, 1.5 \mathrm{yr}\end{array}$} \\
\hline \multirow{2}{*}{\begin{tabular}{|c|} 
vit C $80 \mathrm{mg}$ \\
vit $\mathrm{E} 44 \mathrm{mg}$ \\
$\beta$-carotene $16 \mathrm{mg}$ \\
$\mathrm{Zn} 14 \mathrm{mg}$ \\
Se $0.02 \mathrm{mg}$ \\
+13 others \\
\end{tabular}} & $187 / 375$ & $212 / 373$ & \begin{tabular}{|c|}
0.88 \\
$(0.72-1.07)$ \\
\end{tabular} & URI \\
\hline & $212 / 375$ & $243 / 373$ & \begin{tabular}{|c|}
0.87 \\
$(0.72-1.04)$ \\
\end{tabular} & LRI \\
\hline
\end{tabular}


All studies in this table were placebo-controlled, double-blind randomized trials.

Abbreviations: RR, risk ratio; CI, confidence interval; URI, upper respiratory infection; LRI, lower respiratory infection.

${ }^{a}$ Only the most relevant vitamins and minerals for this review are listed.

${ }^{\mathrm{b}}$ Many trials reported only the average number of episodes and the total number of episodes was calculated for this table. All RR estimates were calculated using the STATA poisson program, except the Barringer trial [112], which was calculated using the STATA glm program with the loglink function.

${ }^{c}$ Chavance et al. [109] collected data "dealing with diagnosis or symptoms of respiratory, nose, throat, ear, skin, mouth, urinary and gynecologic infections." However, Chavance et al. do not describe what proportion of infections was respiratory.

d Girodon et al. [110]: "Only respiratory and symptomatic urogenital infections were collected." However, Girodon et al. do not describe what proportion of infections were respiratory and urinary.

${ }^{\mathrm{e}}$ Girodon et al. [111]: "Respiratory tract infections were based on clinical symptoms (cough, fever, and purulent sputum) and radiological test results." However, Girodon et al. do not describe what proportion of respiratory infections were URI and LRI.

${ }^{\mathrm{f}}$ Graat et al. [92]: "Main outcomes were incidence and severity of acute respiratory tract infections assessed using a diary in which participants, who received thorough instructions, recorded all acute symptoms." However, Graat et al. do not describe what proportion of respiratory infections were URI and LRI.

${ }^{\mathrm{g}}$ Barringer et al. [112]: " $42 \%$ of participants had URI, 19\% had influenza-like syndromes, $7 \%$ had LRI. $20 \%$ of persons experienced more than one type of infection over the study year."

${ }^{\mathrm{h}}$ Avenell et al. [113] describe that $50 \%$ of the number of days of self-reported infections were URI and $20 \%$ were LRI. 
Table 5: Zinc lozenges for treating the common cold

\begin{tabular}{|l|c|c|c|c|c|}
\hline Study [ref.] & $\begin{array}{c}\text { No. of } \\
\text { participants }\end{array}$ & $\begin{array}{c}\text { Zn dose } \\
(\mathbf{m g} / \mathbf{d}) \mathbf{a}\end{array}$ & $\begin{array}{c}\text { Days of } \\
\text { symptoms } \\
\text { Zn/Placebo }\end{array}$ & $\begin{array}{c}\text { Effect } \\
\text { of Zn }\end{array}$ & $\mathbf{P}^{\mathbf{b}}$ \\
\hline & & & & & \\
\hline Eby 1984 [120] & 65 & 207 & $3.9 / 10.8$ & $-64 \%{ }^{\mathrm{c}}$ & $<0.001$ \\
\hline Smith 1989 [134] & 110 & 207 & $5.5 / 7.0$ & $-22 \%^{\mathrm{d}}$ & 0.02 \\
\hline Godfrey 1992 [135] & 73 & 192 & $4.9 / 6.1$ & $-21 \%$ & 0.048 \\
\hline Prasad 2008 [136] & 50 & 92 & $4.0 / 7.1$ & $-44 \%$ & $<0.001$ \\
\hline Petrus 1998 [137] & 101 & 89 & $3.8 / 5.1$ & $-25 \%$ & 0.008 \\
\hline Turner 2000 [138] & 139 & 80 & $6.0 / 5.5$ & & \\
\hline Mossad 1996 [139] & 99 & 80 & $4.4 / 7.6$ & $-42 \%$ & $<0.001$ \\
\hline Prasad 2000 [140] & 48 & 79 & $4.5 / 8.1$ & $-44 \%$ & $<0.001$ \\
\hline Turner 2000 [138] & 139 & 69 & $5.5 / 5.5$ & & \\
\hline Douglas 1987 [141] & $58{ }^{\mathrm{e}}$ & 64 & $12.1 / 7.7$ & & 0.08 \\
\hline Macknin 1996 [142] & 249 & 55 & $9.0 / 9.0$ & & \\
\hline Weissman 1990 [143] & 130 & 45 & $7 / 6$ & & \\
\hline Turner 2000 [138] & 143 & 30 & $6.0 / 5.5$ & & \\
\hline
\end{tabular}

All studies in this table were placebo-controlled double-blind trials. Weissman et al. [143] did not report the method of allocation, but all the other trials were randomized. All studies examined young and middle-aged adults, except the Macknin et al. [142] trial which examined schoolchildren.

${ }^{a}$ The daily dose of zinc is calculated as the product of elemental zinc dose in the lozenge and the planned or counted number of lozenges per day. The lowest zinc doses in the lozenges were in the Weissman et al. [143] trial and in one arm of the Turner et al. trial [138]: 4.5 and $5 \mathrm{mg} /$ lozenge, respectively, and the highest were in Eby et al. [120] and Godfrey et al. [135] trials: 23 and 23.7 $\mathrm{mg} /$ lozenge, respectively. In some trials, the used lozenges were counted [135-137,139-141] and the mean usage was used to calculate the total zinc per day. In other trials, the planned usage was the basis for the calculation so that dosage "every $2 \mathrm{~h}$ awake" was interpreted as 9 lozenges per day.

${ }^{b}$ The outcome is the average days of symptoms (mean or median) except when otherwise stated. The P-value was recalculated when appropriate data was reported in the paper.

${ }^{c}$ Eby et al. [120] did not report the mean or median duration, but estimated the time half of the participants were cured from an exponential fit of the results.

${ }^{\mathrm{d}}$ Smith et al. [134] reported that "subjects taking zinc gluconate had lower severity scores than those in the corresponding placebo group on days 4 to 7 of treatment. This difference is statistically significant ( $\mathrm{P}=0.02)$." From Smith's figure 2, I measured the days needed for $80 \%$ reduction in severity score, which occurred in the 4 to 7 days time range, and thereby the effect was transformed to time scale for this table. Smith et al. did not observe difference between the study groups in the median duration of colds.

e The number of treatment courses was 63; some of the 55 participants had more than one cold episode. 


\section{Fig 1}

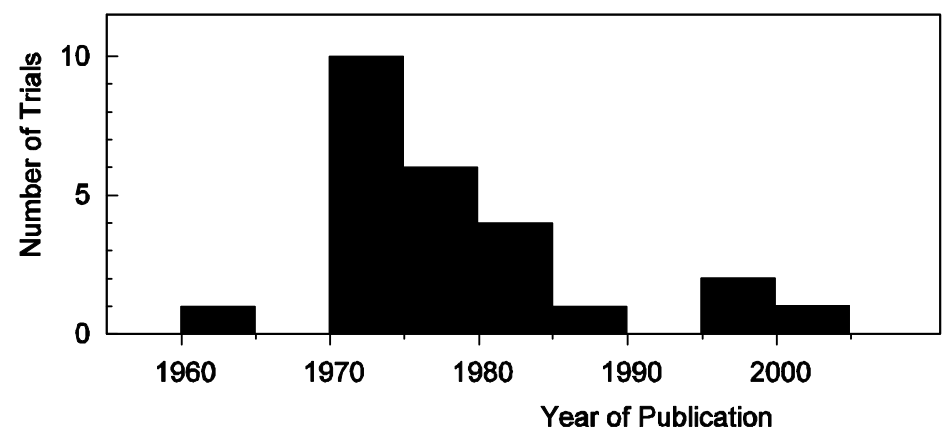

Figure 1. The number of placebo-controlled trials in which $\geq 1 \mathrm{~g}$ /day of vitamin $\mathrm{C}$ was administered regularly to the participants over the study period.

Regular supplementation means initiating supplementation with healthy people and continuing over the occurring common cold episodes. The number of studies published over the five year period is combined. For the list of references up to 1992, see [19]; thereafter Himmelstein et al. reported two trials with $1 \mathrm{~g} /$ day of vitamin C [20] and van Straten and Joslin reported one trial with $1 \mathrm{~g} /$ day of vitamin C [21]. In addition to the large number of trials in the 1970s, the importance of that decade is also reflected by the fact that 5 out of the 6 largest trials so far were carried out in the 1970s [22], and the only large trial published after the 1970s was not published in a medical journal but in a book [23]. 


\section{Fig 2}

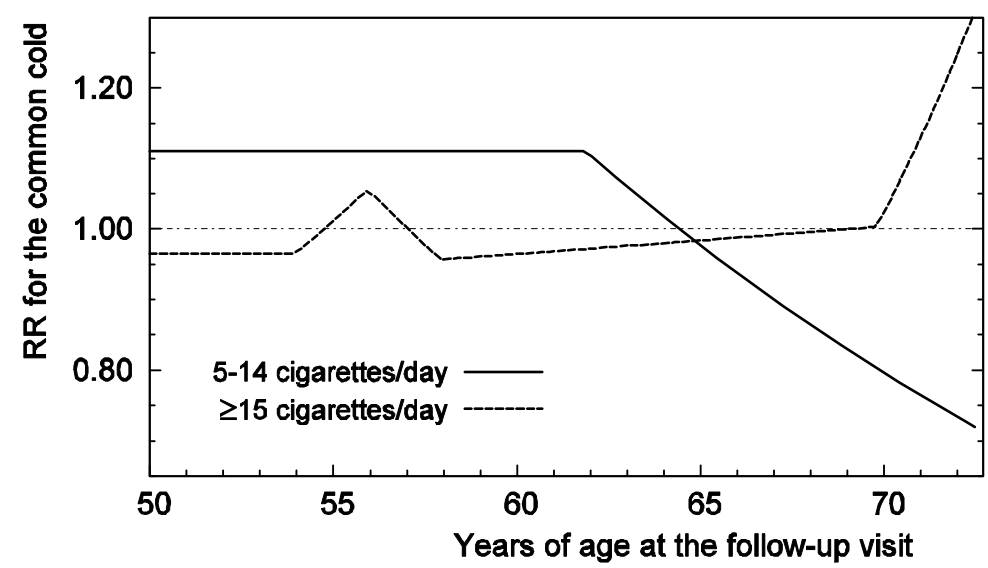

Figure 2. Risk ratio (RR) of the common cold incidence in the vitamin $\mathrm{E}$ arm compared with the placebo arm; the ATBC Study, 1985-1993.

Participants are divided to those who smoked 5 to 14 cigarettes per day at baseline and those who smoked 15 cigarettes or more. The placebo group level is marked by a thin line at the $R R=1.00$. Adding 4 knots to the spline curve of the heavy smokers improves the statistical model by $\chi^{2}(4$ $\mathrm{df})=25.4$, corresponding to $\mathrm{P}=0.00005$. Adding 1 knot to the less smoking participants improves the spline model by $\chi^{2}(1 \mathrm{df})=41.4$, corresponding to $\mathrm{P}=10^{-10}$. Vitamin $\mathrm{E}$ dose was $50 \mathrm{mg} / \mathrm{day}$. These curves are based on 55,770 common cold episodes recorded for 14,573 participants. For the construction of these spline models, see [98], except that the first knot was added at 54 years in these curves. 


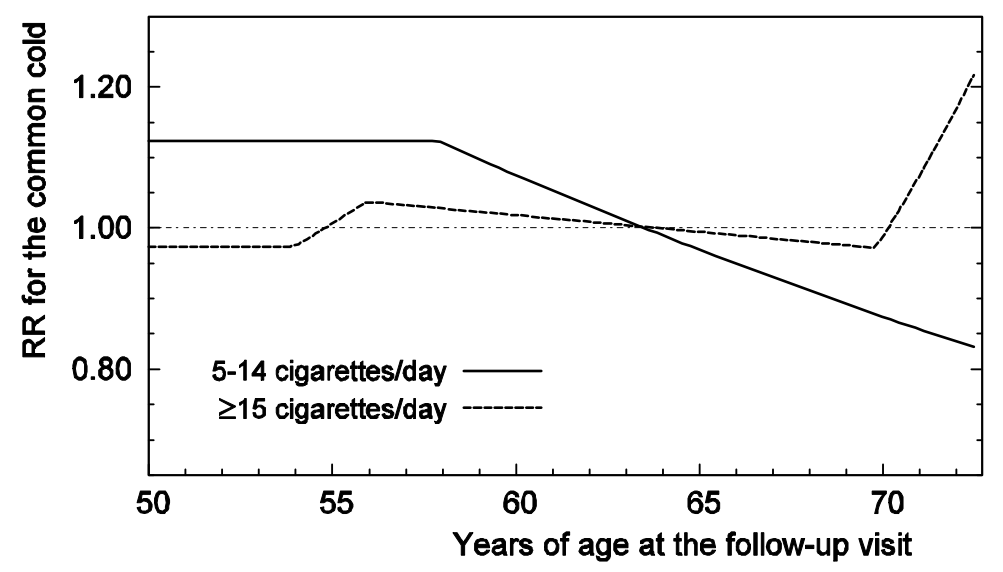

Figure 3. Risk ratio (RR) of the common cold incidence in the $\beta$-carotene arm compared with the placebo arm; the ATBC Study, 1985-1993.

Participants are divided to those who smoked 5 to 14 cigarettes per day at baseline and those who smoked 15 cigarettes or more. The placebo group level is marked by a thin line at the $R R=1.00$. Adding 3 knots to the spline curve of the heavy smokers improves the statistical model by $\chi^{2}(3$ $\mathrm{df})=12.8$, corresponding to $\mathrm{P}=0.005$. Adding 1 knot to the less smoking participants improves the spline model by $\chi^{2}(1 \mathrm{df})=22.6$, corresponding to $\mathrm{P}=0.000002$. $\beta$-Carotene dose was $20 \mathrm{mg} / \mathrm{day}$. These curves are based on 55,905 common cold episodes recorded for 14,569 participants. For the construction of these spline models, see [98], except that the first knot was added at 54 years in these curves. 